https://doi.org/10.15407/scine16.04.083

BUYUN, L.I. ', IVANNIKOV, R.V. ', YAKYMETS, V.M. ${ }^{2}$, STEPANKOV, R.S. ${ }^{3}$, KHARITONOVA, I.P. ${ }^{1}$, and KOZHOKARU, A.A. ${ }^{4}$

'Gryshko National Botanic Garden, the NAS of Ukraine,

1, Timiryazevska St., Kyiv, 01014, Ukraine,

+380 442852647, nbg@nbg.kiev.ua

${ }^{2}$ Center for Innovative Medical Technologies, the NAS of Ukraine,

22, Voznesensky Uzviz, Kyiv, 04053, Ukraine,

+380 44272 2205, cimtnanu@ukr.net

${ }^{3}$ TOPENERGY LLC,

of. 314, 7, Mykola Vasilenko St., Kyiv, 03680, Ukraine,

+38044220 9013, roman@topenergy.com.ua

4 Ukrainian Military Medical Academy of the Defense Ministry of Ukraine,

45/1, build. 33, Moscowska St., Kyiv, 01015, Ukraine,

+38044280 0034, umma@ukrpost.ua

\title{
PHYTOMODULE CLUSTER AS A STRUCTURAL ELEMENT OF INDOOR AREA OF VARIOUS FUNCTIONAL PURPOSES
}

Introduction. To date, people are surrounded by new toxic substances accompanying the development of technological progress, therefore the searching a new ways for amelioration of indoor air quality has acquired an increasing urgency.

Problem Statement. Nowadays, the development of methods for phytoremediation of indoor environment of premises, especially those where congestion of a significant number of people for a long time takes place (treatment and preventive care establishments, classrooms, military barracks or housing accommodations) is increasingly necessary.

Purpose. To create cluster of phytoremediation modules to be used for amelioration of indoor air quality.

Materials and Methods. The anatomical and morphological, physiological and biochemical, microbiological methods, light and SEM microscopy methods were used in the work.

Results. The selection of plants as biofilters with high potency to absorb the harmful substances from indoor air within the collection of tropical plants of Gryshko National Botanic Garden has been undertaken.

The quantitative and qualitative criteria of both the leaf structure and the photosynthetic apparatus, determining the ability of plants to absorb pollutants, were assessed. Biotechnological methods of plant propagation, involved in phytounits have been worked out. Different types of containers with an automatic watering system and substrata with low part of organic substances have been proposed. Additionally, plant compositions were equipped by LED lamps elaborated to provide plants with optimal full spectrum for photosynthetic performance. The screening of antimicrobial activity of phytounits was undertaken in the departments of the Center for Innovative Medical Technologies. It has been established that an air contamination by Staphylococcus saprophyticus after two-week exposition was reduced by half.

Citation: Buyun, L.I., Ivannikov, R.V., Yakymets, V.M., Stepankov, R.S., Kharitonova, I.P., and Kozhokaru, A.A. Phytomodule Cluster as a Structural Element of Indoor Area of Various Functional Purposes. Sci. innov. 2020. V. 16, no. 4. P. 83-97. https://doi.org/10.15407/scine16.04.083 
Conclusions. Thus, phytomodules, including the plants species which are nontoxic, with high remediation ability and tolerant to various abiotic factors have been provided to be introduced into indoor area of treatment and preventive care establishments and closed deployment places of security forces units.

Keywords : tropical plants, phytoremediation modules, antimicrobial activity, adaptive ability, and smart phytolamps.

In the era of global environmental crisis, the problem of xenobiotic pollution is getting more and more important. There is an urgent need to improve the air quality in cities, while the content of pollutants in the indoor air, as compared with the outdoor urban areas, is 10 times higher [1]. However, according to U.S. Environment Protection Agency (EPA, USA) [12] people spend $80-90 \%$ of time indoors, which makes the problem of optimizing their environment especially relevant.

Contamination of the indoor air environment with xenobiotics (formaldehyde, xylene, toluene, carbon monoxide and dioxide, nitrogen monoxide and dioxide, sulfur oxides, etc.) leads to various symptoms (headache, irritation of mucous membranes, etc.) and the "sick building syndrome", from which residents of megacities suffer around the world [2, 3]. Some researchers have suggested that there is a link between long-term exposure to low concentrations of volatile organic compounds (VOCs) and an increased risk of cancer [4-6].

Hospital-type facilities are characterized by a certain list of pollutants related to the specifics of their operation. In particular, it is known that the most typical pollutants of the hospital air environment are as follows: carbon monoxide ( $\mathrm{CO}$ ) and dioxide $\left(\mathrm{CO}_{2}\right)$, lead $(\mathrm{Pb})$, nitrogen dioxide $\left(\mathrm{NO}_{2}\right)$; ozone, volatile organic compounds, sulfur dioxide $\left(\mathrm{SO}_{2}\right)$, formaldehyde $\left(\mathrm{CH}_{2} \mathrm{O}\right)$, and glutaraldehyde $\left(\mathrm{C}_{5} \mathrm{H}_{8} \mathrm{O}_{2}\right)$. Recently, the list of harmful substances has been supplemented by 2-ethylhexanol that is formed by hydrolysis of di-2-ethylhexyl phthalate (DEHP), a plasticizer used in the manufacture of electrical cables [7].

A separate group, the so-called "biopollutants", is formed by pathogens of nosocomial bacterial infections, which pose a threat to patients and health care professionals [8-10]. Such infections occur frequently and lead to many complications and an increase in mortality, not only in developing countries but also in advanced economies. In addition, nosocomial infection is often caused by drug-resistant microorganisms, including the methicillin-resistant Staphylococcus aureus strain (MRSA) and gram-negative bacteria that produce $\beta$-lactamase [11]. In this regard, there are many technical recommendations for creating optimal hygienic conditions in health care facilities.

In view of the above, one of the ways to improve the air environment of health care institutions is the use of plants that have phytoremediation properties. Therefore, the purpose of this research is to create and implement clusters of "phytomodules" of tropical and subtropical plants in health care facilities and recreation centers to harmonize and improve the indoor air.

Achieving the purpose involves many experimental studies aiming at studying the phytoremediation potential of tropical plants and developing practical measures for the rational use of cluster phytomodules in premises of health care facilities, given the specifics of their operation. The therapeutic inpatient departments of the Center for Innovative Medical Technologies of the NAS of Ukraine have been selected as an experimental platform for the implementation and testing of the effectiveness of phytomodules.

The Gryshko National Botanical Garden has been dealing with developments aiming at the use of tropical plants for the rehabilitation of the air environment for more than 40 years. These studies are associated primarily with the research works of Full Member of the NAS of Ukraine A.M. Grodzinsky and Associate Member of the NAS of Ukraine, prof. T.M. Cherevchenko and their students [13-22]. The experimental part of 
the works has been done at the Department for Tropical and Subtropical Plants of the Gryshko National Botanical Garden of the NAS of Ukraine.

In total, among the 131 species of tropical plants studied, 50 species from 15 families of flowering plants (angiosperms) have been selected to create "phytomodules": Amaryllidaceae, Asparagaceae, Araceae, Araliaceae, Arecaceae, Begoniaceae, Bromeliaceae, Commelinaceae, Euphorbiaceae, Lamiaceae, Malaceae, Moraceae, Piperaceae, Saxifragaceae, Vitaceae, as well as representatives of Polypodiophyta. The research objects are selected based on the presence of phytoremediation ability, the characteristics of which have been identified while processing many literature sources or discovered as a result of authors' own research.

\section{ANALYSIS OF ANATOMICAL AND MORPHOLOGICAL STRUCTURE OF PLANT LEAVES IN GREENHOUSE CONDITIONS}

Determining the relationship between the life forms and the functions of plants is a priority in studying ways of organism adaptation to environmental conditions. The anatomical structure of the leaf is considered one of the diagnostic features based on which one can conclude on the reaction of plants to changes in growing conditions.

The quantitative and anatomical features of the leaf, namely, the size of the cells of the upper and lower epidermis, the thickness of their outer wall, the size of the stomata and their number per unit of leaf surface, the development of palisade and spongy parenchyma and other indicators determine the ability of plants to absorb harmful impurities from indoor air. It should be noted that such indicators as the thickness of the leaf blade and the number of stomata vary within one species. The more stable indicators are the number of mesophile layers, the closeness of its cells, the pattern of the stomata location and the number of subsidiary cells (type of stomata).

In general, there have been studied the features of the respiratory system in 131 species of tropical plants belonging to 15 families, in which the main trends in the development of plant adaptations at different structural levels have been identified, which provides for the possibility of different reactions to changes in temperature and water conditions, indoor lighting, as well as the ability to absorb harmful impurities from the air.

As an example, we present the results of anatomical and stomatographical analysis for the wo genera, Sansevieria Thunb. (Asparagaceae Juss.) and Ficus L. (Moraceae Link.), which belong to the two classes of angiosperms, Liliopsida and Magnoliopsida, respectively.

When studying the features of the structural organization of the leaf blade in 12 species of the genus Sansevieria, it has been found that the species within the genus show a high ecological plasticity. The presence of stomata on the underside and upper side of the leaf provides intensive diffusion of water vapor and transpiration. This, in turn, stimulates more intensive movement of minerals, improves the carbohydrate nutrition of plants by increasing the amount of carbon dioxide. A reduction in the number of stomata per unit of leaf surface and in their size in species such as S. senegambica Baker and S. cylindrica Bojer ex Hook. indicates that because of limited gas exchange there is a sharp decrease in the supply of toxic gaseous substances, which allows the use of these plants for phytodesign in the most extreme conditions of industrial premises. That is, the plant, without losing its vital potential, constantly neutralizes harmful air impurities.

Twelve species of the Ficus genus from the $\mathrm{Mo}$ raceae family are characterized by the following structural organization of the leaf blade: the presence of stomata on the lower epidermis as well as thickened and densely arranged cells of the palisade mesophile, which indicate a high photosynthetic capacity of leaves (Fig. 1). The total number of epidermal cells per unit of leaf surface, except for the two species, F. elastica Roxb. ex Hornem. and F. benghalensis L., is rather high. The chloroplasts occupy a significant portion of the cell volume, the plastids are small in size and are arranged parastrophically. This can be seen especially clearly 


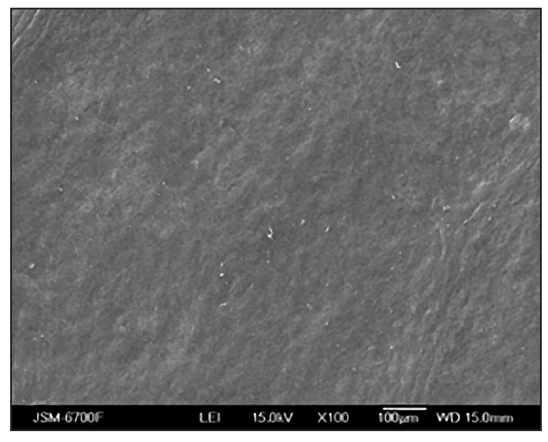

$a$

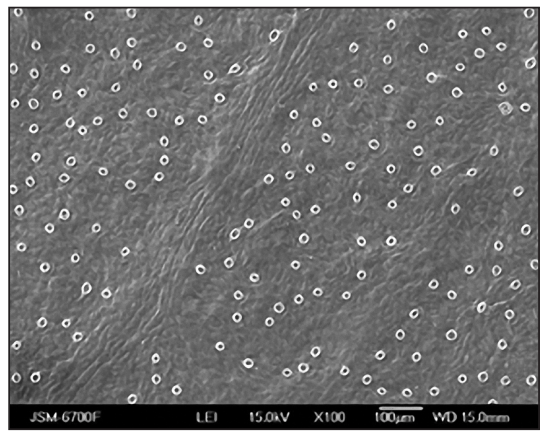

$b$

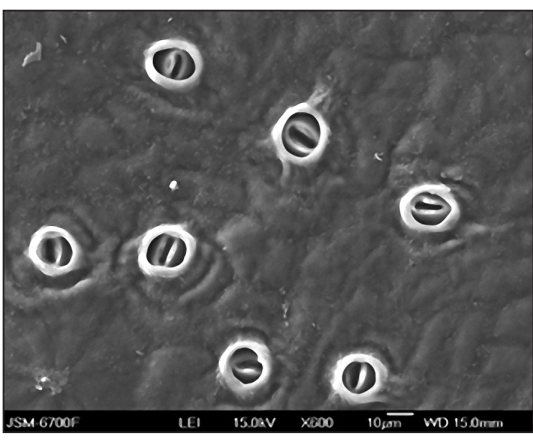

$c$

Fig. 1. Micromorphology of the leaf surface of Ficus benjamina L.: $a$ - adaxial surface; $b$ - abaxial surface; $c$ - stomata

in the palisade parenchyma. The plastid apparatus is distinguished by a high surface density of chloroplasts, which is caused by the stimulating effect of light on the replication of chloroplasts and the dense cellular structure of the leaves. The presence of small stomata is a sign of a low diffusion resistance, which increases the gas resistance of plants. This structural organization of the leaf implies an average shade tolerance of plants, a low water efficiency, an average salt status and an average productivity. An example of the most shadetolerant species is F. pumila L.

The obtained results have shown that the ecologically conditioned convergent features can be traced in the organization of the photosynthetic apparatus of systematically distant plants (Sansevieria Thunb. (Asparagaceae Juss.) and Ficus L. (Moraceae Link.)). Thus, the species grown in a poorly illuminated office interior (or in the hospital conditions) are characterized by a decrease in the concentration of chloroplasts per unit of the leaf surface, increasing the content of photosynthetic pigments. Conversely, under the conditions of industrial interior with illumination in the range of 3.0-5.0 klx, the surface density of chloroplasts is quite high, due to an increase in their number. At the same time, the leaf area decreases and so does the mesophilic cell size.

Thus, the obtained indicators of the anatomical structure of the leaves have complemented the general biological characteristics of the plants of the studied species and expanded the understan- ding of the ability of plants to adapt to interior conditions of different functional purposes.

\section{BIOTECHNOLOGICAL METHODS OF PLANT PROPAGATION TO CREATE "PHYTOREMEDIATION MODULES"}

One of the significant advantages of phytoremediation, as compared with the conventional bioremediation strategies, is its low cost. However, it has disadvantages as well, one of which is the presence of certain restrictions on the growth rate of plants and methods for their reproduction. The last can be addressed by applying modern biotechnological methods for reproduction [23].

The research is based on the previous studies in this field for plants from closely related families, in general, and members of the genus Sansevieria, in particular [24]. The scheme of microclonal propagation method consists of several stages: obtainment of callus tissues from leaf explants, initiation of the hemogenesis processes in callus and obtainment of sprouts, rooting of regenerating plants and their subsequent post-aseptic adaptation. At different stages of micropropagation, the Murashige-Skoog and Pierik media have been used (Fig. 2).

The plant material is selected from intact plants in October. The sterile culture is obtained from leaf explants. The sterilization procedure consists of several stages, with the use of alcohol (70\%) for 2 minutes; thimerosal ( $0.01 \%$ ) for $17 \mathrm{~min}$; chlo$\operatorname{rax}(10 \%)$ for 15 minutes; and $\mathrm{H}_{2} \mathrm{O}_{2}$ for $8 \mathrm{~min}$. 

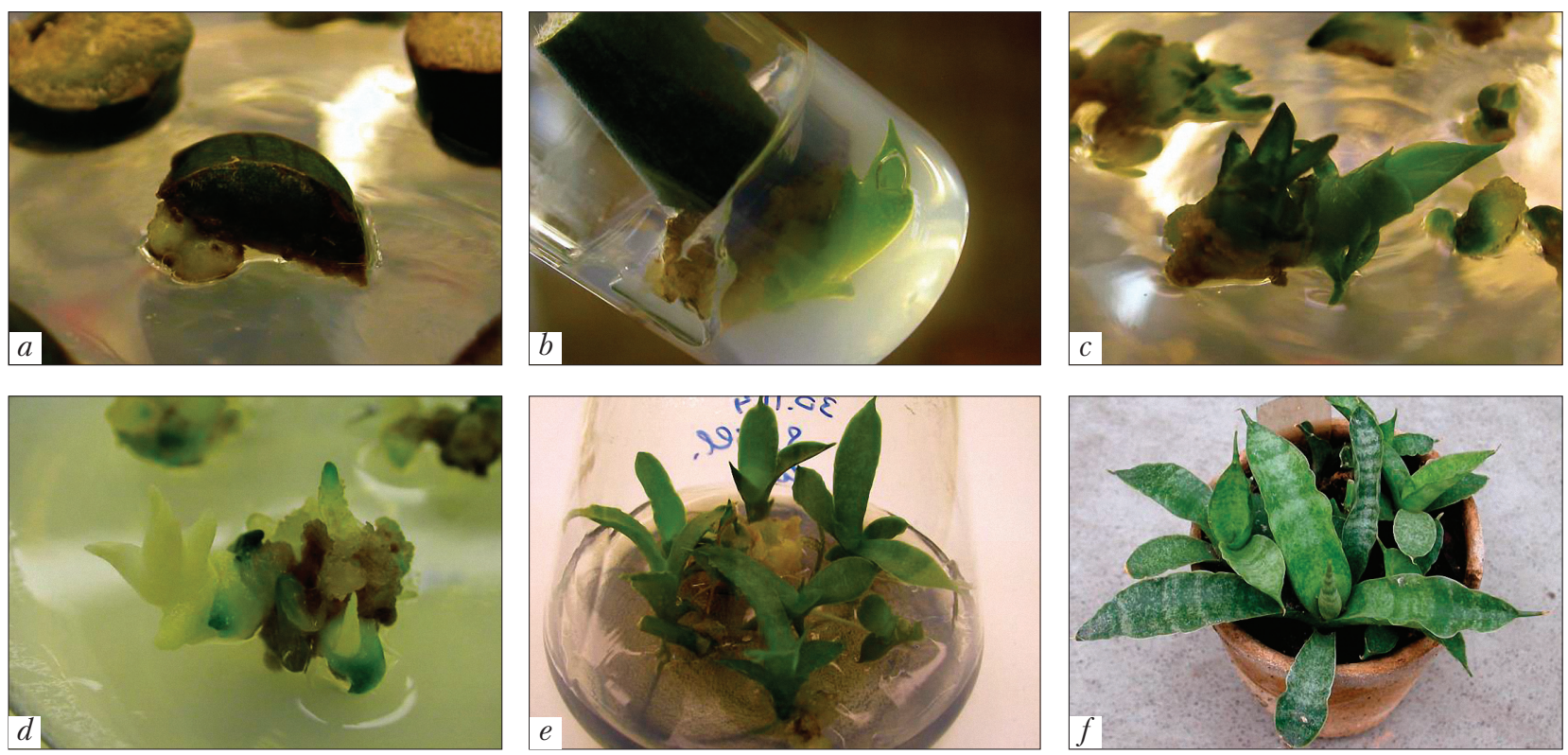

Fig. 2. Stages of microclonal propagation of Sansevieria cylindrica Bojer ex Hook.: $a$ - the formation of solid morphogenic callus on primary explants; $b, c$ - indirect organogenesis - the formation of the first micro sprouts; $d$ - the formation of etiolated micro sprouts in the dark conditions; $e, f$ - regenerating plants $(e-$ in vitro; $f-$ ex vitro $)$

Analyzing the results related to the regeneration and subsequent organogenesis of callus tissues of $S$. cylindrica, we note that the highest frequency of regeneration has been reported for the Pierik medium with $1 \mathrm{mg} / \mathrm{l}$ benzylaminopurine (6-BAP). Moreover, in the dark conditions, these processes are more intensive than in the illuminated ones.

Later, such sprouts are separated from the callus and transferred to light. Each of them is divided into separate segments by the number of internodes. From the axillary buds of each underdeveloped leaf of regenerating plants on the MS medium (with $4 \mathrm{mg} / \mathrm{l}$ adenine) in the illuminated conditions, there is formed a separate rosette that eventually takes root on the same medium. After 45-55 days, the plants suitable for planting in the substrate are obtained. Thus, combining the methods of illuminated and dark cultivation, the number of obtained regenerating plants increases 2-4 times.

In a series of experiments under the illuminated conditions, Pierik's media has been found the most effective. The regenerated plants are planted in a pre-sterilized substrate (2 atm,. at $130{ }^{\circ} \mathrm{C} / 2 \mathrm{~h}$ ) that consists of leaf-mould soil and sand (1:1). The post-aseptic adaptation of regenerating plants is carried out in a climatic chamber: at a relative humidity of $80-90 \%$, a temperature of $23-25{ }^{\circ} \mathrm{C}$, for 8 hours, in the daylight conditions. In these conditions, the regenerating plants adapt for $100 \%$, and after 35-40 days, they are transferred to greenhouse conditions. The cylindrical leaves typical for generative plants of this species appear in the regenerating plants only after 120-150 days.

According to a similar scheme, biotechnological methods of reproduction have been developed for many species from other families, whose representatives are recommended for the use in cluster phytomodules.

\section{ESTIMATION OF PHYTONCIDE ABILITY OF PLANTS OF INDIVIDUAL SPECIES, WHICH ARE PART OF "PHYTOMODULES"}

The plants have been proved to be able to absorb dust, harmful toxic chemicals, to reduce the amount of carbon dioxide in the indoor air, to hu- 
midify and to ionize the air, and to inhibit the development of many pathogenic microorganisms [25]. Indoors, due to variety of life forms, colors, and smells, the plants create an illusion of contact with wildlife and have a favorable effect on the central nervous system, help to improve emotional state and to relieve stress.

It is known that under the same growing conditions, the phytoncidal activity of plants depends on their species characteristics. At the same time, the tropical plants retain the ability to release volatile compounds throughout the year, although the quantity of them is determined by climatic conditions and phases of plant development [25].

In view of the above, a series of experiments has been carried out to study the phytoncide properties of different plant species. At the first stage of the experiment, 6 species of plants from the Araceae family, which differ significantly in the structure and color of leaves (Aglaonema commutatum Schott, Anthurium andraeanum Linden ex André, Dieffenbachia macrophylla Poepp. (syn. D. maculata (Lodd.) Sweet), Thaumatophyllum bipinnatifidum (Schott ex Endl.) Sakur. (syn. Philodendron bipinnatifidum Schott ex Endl.), Epipremnum aureum (Linden \& André) G.S. Bunting (syn. Scindapsus aureus (Linden \& André) Engl.), Spathiphyllum blandum Schott) have been selected as objects of study.
The experimental plants are kept in a special box. The colonies of microorganisms are counted after 24 and 48 hours. The Petri dishes with test cultures placed in a similar box, but without plants, are used as reference samples. The phytoncidal activity of experimental species is studied using the most common test cultures of microorganisms, in particular Staphylococcus aureus, Staphylococcus saprophyticus, Staphylococcus epidermidis, Streptoccocus pyogenes ( $\beta$-hemolytic streptococcus group A), Microccocus luteus, Klebsiella pneumoniae, Pseudomonas aeruginosa, and Escherichia coli.

The obtained results indicate that all studied plant species have an antimicrobial action. The comparative analysis of the photosynthetic activity of the studied species has given interesting results (Table 1). In particular, for the plants $P h . b i-$ pinnatifidum, characterized by a high phytoncide ability, the photosynthesis intensity is $22 \mathrm{mg}$ of $\mathrm{CO}_{2}\left(\mathrm{dm}^{2} / \mathrm{h}\right)$, while for $D$. macrophylla, it is only $4 \mathrm{mg}$ of $\mathrm{CO}_{2}\left(\mathrm{dm}^{2} / \mathrm{h}\right)$.

A similar regularity has been found while studying the pigment complex of the leaves. Thus, the plant tissues of species characterized by maximum phytoncidal ability have a high content of chlorophyll. The data in Table 1 show that the total amount of chlorophyll in the leaves of Thaumatophyllum bipinnatifidum is $290.4 \mathrm{mg} / 100 \mathrm{~g}$, and that in D. macrophylla is $45.8 \mathrm{mg} / 100 \mathrm{~g}$ of plant mass.

Table 1. Phytoncidal activity of the Studied Species from Araceae Juss. Family

\begin{tabular}{|c|c|c|c|c|c|}
\hline \multirow{3}{*}{ Species } & \multirow{3}{*}{$\begin{array}{l}\text { Photosynthesis } \\
\text { intensity, } \\
\mathrm{mg} \mathrm{CO}_{2} \\
\left(\mathrm{dm}^{2} \cdot \mathrm{g}\right)\end{array}$} & \multicolumn{4}{|c|}{ Content of photosynthetic pigments, $\mathrm{mg} / 1000 \mathrm{~g}$ crude substance } \\
\hline & & \multicolumn{3}{|c|}{ Chlorophyll } & \multirow{2}{*}{ Carotenoids } \\
\hline & & $a$ & $b$ & $a+b$ & \\
\hline Aglaonema commutatum & 5 & 59.6 & 18.6 & 78.2 & 23.8 \\
\hline Anthurium andraeanum & 8 & 90.8 & 27.6 & 118.4 & 33.8 \\
\hline Dieffenbachia macrophylla & 4 & 37.1 & 8.6 & 45.7 & 15.8 \\
\hline $\begin{array}{l}\text { Thaumatophyllum bipinnatifidum (syn. Philo- } \\
\text { dendron bipinnatifidum) }\end{array}$ & 22 & 237.7 & 52.6 & 290.3 & 68.8 \\
\hline Epipremnum aureum & 20 & 224.0 & 43.8 & 267.8 & 64.3 \\
\hline Spathiphyllum blandum & 15 & 181.6 & 32.0 & 213.6 & 50.3 \\
\hline $\mathrm{HCP}_{0.05}$ & - & 7.93 & 1.28 & - & 3.41 \\
\hline
\end{tabular}


Thus, the obtained results indicate a direct relationship between the anatomical and physiological parameters of the photosynthetic apparatus and the phytoncidal ability of plants. The prospects for using all experimental species for the rehabilitation of the airspace of the premises have been proved. In addition, the level of bactericidal activity and photosynthetic productivity of plants can be used as a test to determine the ecological plasticity of different species in order to introduce them into landscaping.

In recent years, woody plants, including ficus, schefflera, and hibiscus, which have an ornamental crown, a bright color of whole or dissected leaves, and ornamental inflorescences, have been widely used for landscaping interiors of various functional purposes. In addition to ornamental function, as the studies have shown, these plants are characterized by a high phytoncidal activity. Therefore, at the second stage of the experimental research, 6 species of the Ficus genus have been selected as objects: F. benjamina, F. benjamina Exotica with green leaves up to $10 \mathrm{~cm}$ long; F. benjamina Golden King with golden-yellow leaves; F. elastica with large, up to $35 \mathrm{~cm}$ long, glossy dark green leaves; $F$. elastica Rubra with a dark greencherry color of the leaf blade; and F. pumila, a liana with small, greenish-white leaves up to $3 \mathrm{~cm}$ long. The obtained results have shown that all selected species are characterized by different phytoncide ability against pathogenic microorganisms (Table 2).

The highest inhibitory effect on pathogens has been found in the F. pumila. plants. The plants of
F. elastica inhibit the growth of Staphylococcus aureus, by $71-73 \%$, whereas $F$. benjamina has a high phytoncidal activity against $S$. saprophyticus and S. epidermidis.

It should be noted that all experimental plants have shown a high phytoncidal activity against Staphylococcus aureus, S. saprophyticus and S. epidermidis, the most dangerous microorganisms for humans. The microorganisms Klebsiella pneumoniae, Pseudomonas aeruginosa, and Escherichia coli are less sensitive. All species selected for the experiment, except for F. pumila, have no bactericidal action against Streptococcus pyogenes and Micrococcus luteus.

Thus, the high adaptability of plants of the $\mathrm{Fi}$ cus genus and members of the Araceae family to various growing conditions, their ornamental properties and high phytoncidal activity give reason to recommend them for widespread use in interior greening.

When assessing the sanitary condition of indoor areas, depending on the objectives of the study, we have carried out a total microbial count and determined the presence of sanitary-indicative microorganisms (staphylococci, streptococ$\mathrm{ci}$ as indicators of contamination with the microflora of the human nasopharynx). Based on the above data, to study the overall microbial composition of the air, air samples from the premises of the lobby area of the surgical department and the rehabilitation department have been plated.

Using the methods generally accepted in clinical microbiology, the antimicrobial activity of phytomodules has been screened in the condi-

Table 2. Phytoncidal Activity of Ficus L. Genus, \% of Inhibition of Pathogenic Microorganism Growth

\begin{tabular}{|l|c|c|c|c|c|c|c|c|}
\hline \multicolumn{1}{|c|}{ Species } & S. aureus & $\begin{array}{c}\text { S. sapro- } \\
\text { hyticus }\end{array}$ & $\begin{array}{c}\text { S. epider } \\
\text { midis }\end{array}$ & $\begin{array}{c}\text { Streptococcus } \\
\text { pyogenes }\end{array}$ & $\begin{array}{c}\text { Micrococcus } \\
\text { luteus }\end{array}$ & $\begin{array}{c}\text { Klebsiella } \\
\text { pneumoniae }\end{array}$ & $\begin{array}{c}\text { Pseudomonas } \\
\text { aeruginosa }\end{array}$ & $\begin{array}{c}\text { Escherichia } \\
\text { coli }\end{array}$ \\
\hline Ficus benjamina & 44.3 & 85.5 & 68.3 & 5.7 & 12.8 & 11.4 & 48.4 & 19.1 \\
F. benjamina 'Exotica' & 48.1 & 67.3 & 51.5 & 8.1 & 9.4 & 9.8 & 22.8 & 19.3 \\
F. benjamina 'Golden King' & 33.8 & 35.3 & 32.2 & 3.9 & 7.5 & 29.2 & 18.7 & 22.3 \\
F. elastica & 71.2 & 12.3 & 17.8 & 4.3 & 3.8 & 4.9 & 43.4 & 20.1 \\
F. elastica 'Rubra' & 73.5 & 13.8 & 13.2 & 10.5 & 2.1 & 8.1 & 48.1 & 21.3 \\
F. pumila & 43.8 & 78.2 & 67.3 & 80.3 & 53.4 & 5.4 & 9.6 & 55.2 \\
HCP $_{0.05}$ & 6.54 & 1.98 & 2.11 & 1.35 & 0.83 & 1.07 & 3.28 & 2.56 \\
\hline
\end{tabular}


tions of inpatient departments of the Center for Innovative Medical Technologies of the NAS of Ukraine. Before the start of the experiment, the microbial count of indoor air in the premises where the phytomodules were planned to be localized was done by the aspiration method, using the Krotov device [27]. The total number of microorganisms from the air of the rehabilitation department on 2 Petri dishes was 360 and 50 colonies, while that in the surgical department was 380 and 200 colonies. No sanitary-indicative microorganisms, Staphylococcus aureus and $\alpha$ - and $\beta$-hemolytic streptococci were detected. Two weeks after the placement of phytomodules in the mentioned departments, a repeated microbiological study of the air has been conducted. The results of these studies are shown below (Fig. 3).

According to the results of indoor air contamination study aiming at the detection of the total microbial count per $1 \mathrm{~m}^{3}$ air and sanitary-indicative microorganisms (Staphylococcus aureus, $\alpha$ - and $\beta$-hemolytic streptococci, yeast and mold fungi), a decrease in the number of total microorganisms has been reported as the average number of colonies dropped 1.75 times (from 297.5 colonies to 170 colonies, respectively). So, the number of colonies of Staphylococcus saprophyticus on Petri dishes after two weeks of exposure has decreased 1.75 times, which implies a high phytoncidal activity of plants against this microorganism that is a potential causative agent of nosocomial infections in hospital patients. At the same time, no sanitary-indicative microorganisms ( $\alpha$ - and $\beta$-hemolytic streptococci, Staphylococcus aureus) have been detected.

For each plant species there is a certain set of parameters of the environment, the most optimal for their growth. Slight deviations of individual parameters or their combination determine the zone of tolerance in which plants grow without feeling unfavorable effects of the environment. Significant deviations require from the plant organisms to activate adaptive mechanisms and in the case of very large amplitude of deviations, there occur irreversible changes leading to plant death. The ability of plants to function in interiors, where the main limiting factor is mainly light, can be assessed by numerous methods, each of which is not perfect, but their combined use provides complete information on mechanisms that allow plants to tolerate extreme conditions.

Since plants are typical autotrophs and are completely dependent on photosynthesis, when designing artificial light sources, it is necessary to correctly assess the quantitative and qualitative parameters of light flux. When designing phytolamps, the efficiency of their luminous flux shall be evaluated at the output. For this purpose, efficiency means a combination of two parameters light output (the quantitative characteristic) and spectrum (the qualitative characteristic).

Tropical and subtropical plants used in interior decoration need a balanced sunlight for their normal growth and development. According to this criterion, they are conventionally divided into three main groups: light-loving, shade-tolerant, and shade-indifferent. Plants from the last two groups are mostly used in the formation of plant compositions. These are mainly polycarpics, herbaceous or shrubby undergrowth plants, lianas that can withstand prolonged or significant shading. Usually, they are able to adapt to changing conditions and withstand the conditions of residential premises.

When designing artificial light sources, we tried to take into account the needs of plants in the spectral composition of light as adequately as possible. In terms of the radiation spectrum, sunlight is heterogeneous. It consists of rays of different wavelengths. The length of daylight varies during the year, which has been taken into account while forming the algorithm for lighting the phytomodules, as the length of daylight in places of natural growth of tropical and subtropical plants is relatively constant (10-12 hours) and practically does not vary during the year. In the middle latitudes, the shortest day lasts 8 hours, and the longest one continues for more than 16 hours. In order to eliminate this difference, the smart 

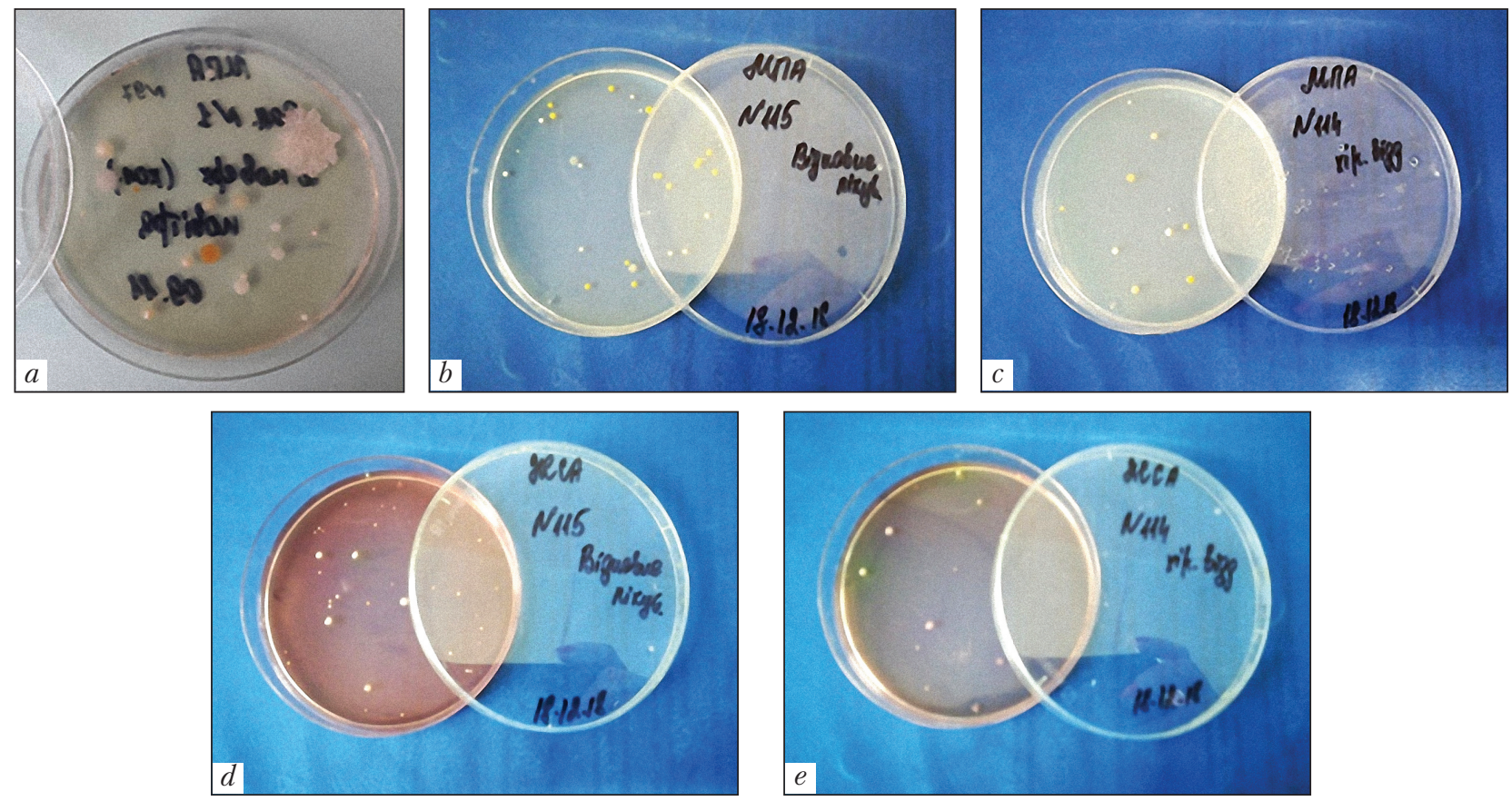

Fig. 3. General view of the Petri dishes with colonies of microorganisms: $a$ - growth of colonies of Staphylococcus saprophyticus before the introduction of phytomodules in the inpatient departments of the Center for Innovative Medical Technologies of the NAS of Ukraine; $b$ - total microbial contamination in the lobby of the surgical department (100 colonies); $c$ - total microbial contamination in the rehabilitation department (240 colonies); $d$ - pscreening results for the presence of Staphylococcus aureus on salt egg-volt agar in the lobby of the surgical department, and $e-$ in the lobby of the rehabilitation department

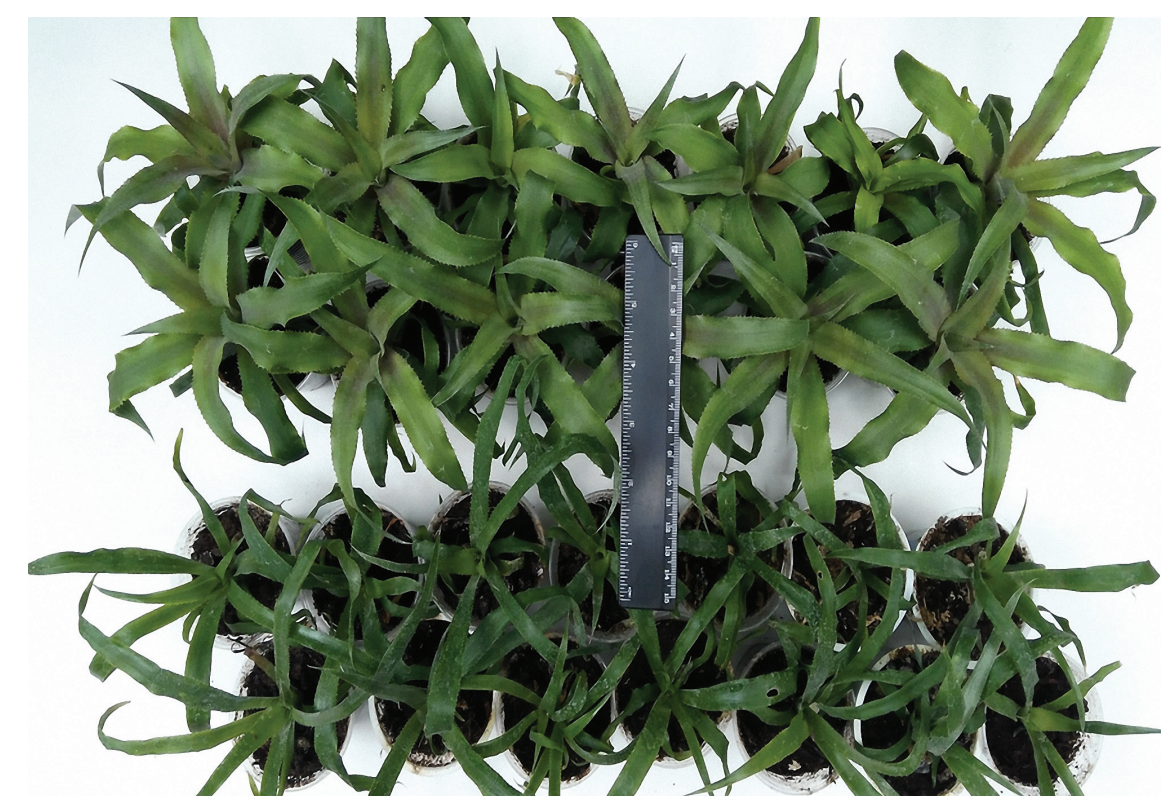

Fig. 4. Reference and experiment groups of regenerating plants Ananas comosus (L.) Merr.: $a$ - smart lamps; $b$ - natural light 

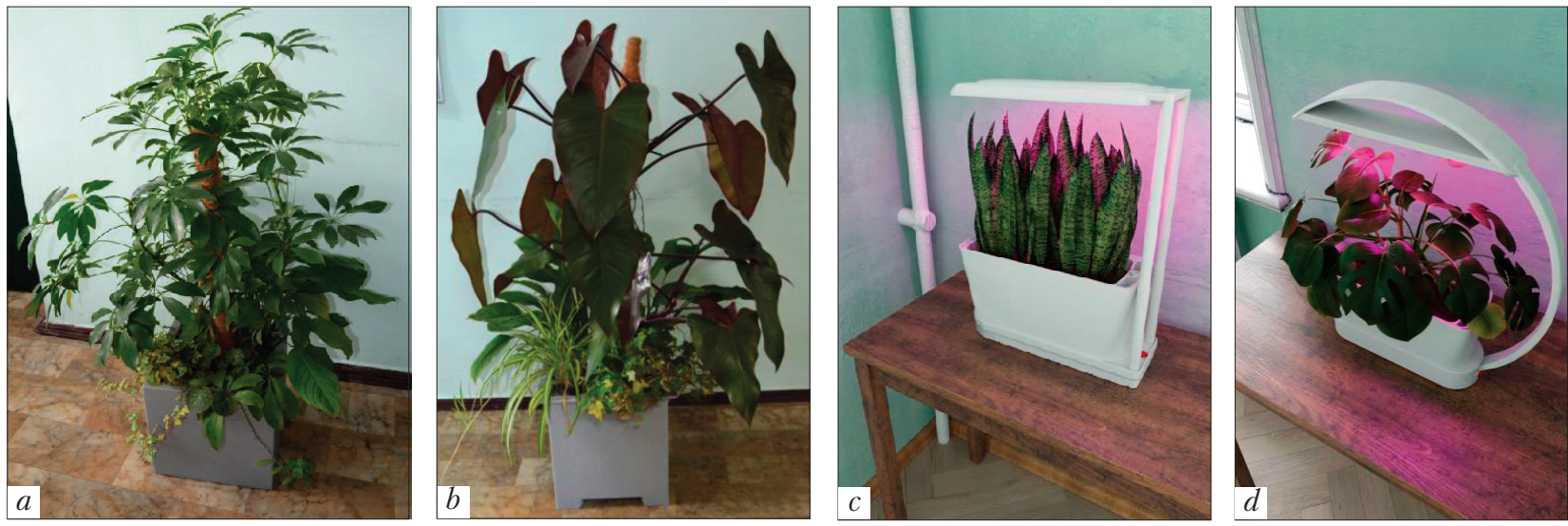

Fig. 5. General view of the compositions in the lobby of the surgical department of the Center for Medical Innovative Technologies of the NAS of Ukraine: $a, b$ - phytomodules without the use of smart phytolamps; $c, d$ - phytomodules with lamps

lamps have built-in controllers capable of maintaining the length of daylight within 12 hours.

The purpose of this stage of research is, given the above aspects, to study the effect of different types of tested lamps on the growth potential of plants of selected species. Proceeding from that, on average, the red LED with a power of $1 \mathrm{~W}$ emits 30-40 lm, the blue one irradiates 20-30 $\mathrm{lm}$, while the white one generates $100-110 \mathrm{~lm}$. On a sunny summer day, at the middle latitude, the daylight integral is about $2000 \mu \mathrm{mole} / \mathrm{m}^{2}$. That of LED lamp with a power of $130 \mathrm{~W}$ at a distance of $30 \mathrm{~cm}$ is approximately $1570 \mu \mathrm{mole} / \mathrm{m}^{2}$. However, it is known that the most favorable for growing light-loving plants are intensities in the range of $150-220 \mathrm{~W} / \mathrm{m}^{2}$, and the optimal composition is as follows: the blue region $(380-490 \mathrm{~nm})$ $30 \%$, the green region (490-590 nm) $20 \%$, and the red region $(600-700 \mathrm{~nm}) 50 \%$. Based on these assumptions, the design smart lamps have been designed. Luminous fluxes of experimental lamps have been studied in terms of spectra. The test lamps have been used as the sole light source. The photoperiod is $12 / 12 \mathrm{~h}$, humidity is $80-90 \%$, and temperature is $22-26{ }^{\circ} \mathrm{C}$. The average distance from the lamp surface to the upper parts of the plants ranges within $30-40 \mathrm{~cm}$.

The analysis of results has shown that the final LED composition of the lamps has better perfor- mance as compared with the fluorescent light sources used in everyday practice. Visually, for different groups of plants, this is displayed in a specific purple tint of the stems and leaves. The vegetative organs acquire typical size and shape and have shorter internodes, as the effect of "elongated" plants disappears (Fig. 4).

The observed positive effects of growth and development of experimental groups of plants are as follows:

- active growth of biomass of experimental groups of plants, which is 1.3-2.2 times higher as compared with the reference samples has been established. Probably, this is a result of more efficient work of both photosystems, which manifests itself primarily in the activation of metabolic reactions associated with the biosynthesis of auxiliary photosynthetic pigments (different types of carotenes, xanthophylls) and their active involvement in photosynthesis and plastic metabolism;

- active growth of biomass, harmonization of morphogenetic processes, and normalization of habit are obviously a result of the effect of the optimized spectrum of lamps. We assume, this makes the operation of the second light-sensitive system possible. In this chain of reactions, phototropin and cryptochromes are responsible for signal perception. They are able to receive a sig- 
nal of this type and to determine the implementation of local solutions: different types of tropisms (determining the direction of maximum illumination, the optimal orientation of the assimilating organs in space, opening/closing of stomata). As a result, the efficiency of photosynthesis increases, water and mineral metabolism gets normalized.

The use of the optimized spectrum of smart lamps leads to the normalization of the phytochrome system. This manifests itself in the formation of vegetative organs (leaves, stems) with a specific morphology of particular species. In addition, for some species the formation of generative organs is reported. We believe, this indicates a balanced luminous flux of the tested lamps of the designed configuration.

The creation of phytocompositions involves several components: the selection of the range of plants with a high phytoremediation capacity, type of containers, plant propagation methods, including the use of biotechnological techniques, and compliance with cultivation technology.

Within the project, 21 phytomodules have been composed (Fig. 5). They differ in the shape of the container (height/width/diameter), the presence/ absence of phytolamps, systematic, biomorphological composition of plants, and therefore, in the phytoremediation ability.

When creating the compositions planted in containers, the plant species capable of absorbing harmful impurities, having increased adaptability, in particular assimilative properties under suboptimal conditions, and maintaining the balance of basic functions in the environment have been selected. Inasmuch as different plant species are able to absorb different groups of pollutants, their combination in the compositions increases the overall phytoremediation capacity. Before planting in containers for the formation of phytomodules, the plants are cultivated in greenhouses. When combining plants, widely available floor, table, and suspended pots of the Lechuza type are used. All pots are equipped with an automatic watering system, so that any plant receives the re- quired amount of water and fertilizer, depending on the pot size, with removable inner containers allowing the change of plant without damaging its root system.

To create optimal conditions for growing ornamental plants indoors, the correct selection of soil substrate is of paramount importance. When preparing it, it is necessary to take into account the physical properties of all components in order to ensure sufficient aeration of the root zone, a stable structure and a high buffering capacity. A significant amount of natural and synthetic materials as soil substrates have been studied in the research. The most suitable for the indoor cultivation of ornamental plants are peat products, leaf debris of various species, and fillers of synthetic origin. Mix designs of optimal and relatively cheap substrates although with a low structural stability have been obtained.

A series of experiments to study the effect of nutrients (biogenic elements) on the plant growth and their impact on the ratio of root to herb biomass in the indoor plants has shown that the value of the root: to herb ratio is much higher in the case of nitrogen deficiency. Under these conditions, the length of the roots increases, but their volume remains the same, and the adsorption surface decreases. In the case of more severe nitrogen deficiency (30-50 mg / l of substrate), the following dependence is observed: first, the weight of the roots decreases, then so do their volume and adsorption surface, and finally, the growth of the root system stops. The physiological state of the rhizosphere with a low nitrogen supply is characterized by an increase in water content in the root tissues and a high ratio of $\mathrm{K}$ : $\mathrm{Ca}$. Thus, in the experiment with minimum dose of nitrogen, the water content in the root tissues for all species is, on average, by $21-37 \%$ higher, as compared with that in the plants with optimal nitrogen supply. At the same time, the content of $\mathrm{K}$ in the plant tissues increases, on average, 1.9-2.5 times.

Certain changes in the pattern and size of root systems are associated with agrophysical parameters of soil substrates. It has been experimentally 
proved that the deterioration of the root system in all studied species is observed under conditions of increasing substrate density from 1 to $1.6 \mathrm{mg} / \mathrm{cm}^{3}$, and at $1.88 \mathrm{mg} / \mathrm{cm}^{3}(0.52 \mathrm{MPa})$, the root growth almost completely stops. At the same time, the adsorption of phosphorus, potassium and calcium compounds by roots sharply decreases..

There is a direct relationship between leaf fall and a decrease in the volume of thin roots. This pattern has been observed in indoor ornamental plants in the period from November to February, under conditions of unstable air temperature and low indoor lighting. It has been proved that the state of development of thin roots (namely, weight, length, number of roots, and size of their adsorption surface) is a very sensitive indicator for optimizing the growing conditions of introduced indoor plants of various functional purposes.

For the development of phytomodules for hospitals, the widely available mineral substrate LECHUZA-PON was used. This type of substrate that contains pumice, zeolite, lava and has a NPK ratio of 15:11:14 (as well as trace elements) is chosen because of the need to reduce the share of organic matter in the mix, insofar as it is a favorable medium for the development of microorganisms and fungi, which is unacceptable for hospitals.

Thus, the results have shown that the phytoremediation of indoor air space, including hospitals, is an extremely efficient, cost-effective and environment friendly way to purify the air, which improves physical and psychological health.

Therefore, as an outcome of the project, the methodological framework for the creation and use of indoor ornamental phytomodular compositions from tropical plants at medical and preventive establishments and in the places of a high concentration and long stay of enforcement bodies units (hospitals, barracks, auditoriums) has been developed. The last type of premises is chosen as a model one that has a certain type of air pollutants, and, consequently, requires the use of plant species that can neutralize these substances.
Based on the assessment of phytoremediation capacity of certain species of tropical plants (anatomical, physiological-biochemical, and biological-morphological indicators that determine their effectiveness in improving the indoor air), the NBG collection of tropical plants has been screened in order to find the plants suitable for phytoremediation of indoor air with a specific load of harmful substances, and 21 phytomodules for greening premises of health care facilities have been created.

Quantitative and qualitative criteria for the structure of the leaf surface and photosynthetic apparatus, which determine the ability of plants to absorb harmful substances and to show resistance to stress have been identified. The plants of species belonging to the genera Nephrolepis, Dracaena, Ficus, Peperomia, Thaumatophyllum, Spathyphyllum, Chlorophytum, etc., recommended for phytomodular compositions have shown a high resistance to environment conditions.

The screening of antimicrobial activity of "phytomodules" in the inpatient departments of the Center for Innovative Medical Technologies of the NAS of Ukraine has shown that the amount of Staphylococcus saprophyticus in the air samples after two weeks of exposure has almost halved, indicating a high phytoncide potential of the plants against this causative agent of nosocomial infections in hospital patients.

Among the studied species, the highest phytoncidal activity with respect to pathogenic microorganisms (Klebsiella pneumoniae, Pseudomonas aeruginosa, and Escherichia coli) has been reported in the following plants: Thaumatophyllum bipinnatifidum, Epipremnum pinnatum, and Spathiphylla pumpaum, which gives a reason for recommending their use in the phytomodules for greening interiors of various functional purposes, first of all, health care establishments.

The development of appropriate care regulations and LED smart phytolamps with quantitative and qualitative characteristics of the light flux, which correspond to the optimum of photosynthetic processes enable the effective use of the 
proposed phytomodular systems with minimum financial and labor costs.

Thus, typical "phytomodules" i.e. compositions consisting of certain types of ornamental plants that are non-toxic, have a high remediation capacity and tolerance to various abiotic factors (insufficient moisture, different levels of light intensity, etc.) and, at the same time, are small, which facilitates the plant care have been proposed for implementation. An innovative aspect of this development is that the proposed phytomo- dules are intended for use primarily in hospitals, as well as in the places for a large crowd, like close spaces where law enforcement bodies units are deployed.

Acknowledgements. At the implementation stage, the research was partially funded within the framework of REDD project no.394-FM Implementation of Phytomodules of Tropical Plants to Optimize the Environment of Health Care Facilities (state registration number 0118U000959), for which the authors express their sincere gratitude.

\section{REFERENCES}

1. Vazquez, K., Adams, L. The Level of Volatile Organic Compounds Exposure in New Buildings: Can Adding Indoor Potted Plants Reduce Exposure. (2014, April). Proceedings of The National Conference On Undergraduate Research (NCUR) (April, 3-5). University of Kentucky, Lexington, KY. 531-540.

2. Avaltroni, R., Constantinidis, C., Dipaolo, G., Fields, R., Gallo, R., Glorie, D., Haitoff, J., Holzka, D., Napolitano, M., Nastasi, J., ..., Richard Tobin. (2015). Indoor air quality and sick building syndrome in health care facilities and commercial buildings. 23 p.

3. Burge, P. S. (2004). Sick building syndrome. Occup. Environ. Med., 61, 185-190. doi: 10.1136/oem.2003.008813.

4. Vaughan, T. L., Strader, C., Davis, S., Daling, J. R. (1986). Formaldehyde and cancers of the pharynx, sinus and nasal cavity: II. Residential exposures. Journal of Cancer, 38, 685-688.

5. Wallace, L. A. (1991). Personal exposure to 25 volatile organic compounds Epa's 1987 team study in LosAngeles, California. Toxicology and Industrial Health, 6, 203-208. doi: https://doi.org/10.1177/074823379100700523.

6. Wolkoff, P., Nielsen, G. D. (2001). Organic compounds inindoor air - their relevance for perceived indoor air quality? Atmospheric Environment, 35, 4407-4417. doi: https://doi. org/10.1016/S1352-2310(01)00244-8.

7. Azuma, K., Tanaka-Kagawa, T., Jinno, H. (2016). Health risk assessment of inhalation exposure to 2-ethylhexanol, 2,2,4trimethyl-1,3-pentanediol diisobutyrate, and texanol in in-door environments. Proceedings X International Conference on Indoor Air Quality and Climate (Indoor Air). Proceedings: Indoor Air. Paper ID 168. Ghent: ISIAQ.

8. Kim, K. Y., Kim, Y. S., Kim, D. (2010). Distribution characteristics of airborne bacteria and fungi in the general hospitals of Korea. Ind. Health, 48 (2), 236-243.

9. El-Sharkawy, M. F. Noweir, M. E. (2014). Indoor air quality levels in a University Hospital in the Eastern Province of Saudi Arabia. J. Family Community Med., 21 (1), 39-47.

10. Dehghani, M. (2018). Concentration and type of bioaerosols before and after conventional disinfection and sterilization procedures inside hospital operating rooms. Ecotoxicol. Environ. Saf., 164, 277-282.

11. Melzer, M., Welch, C. (2013). Outcomes in UK patients with hospital-acquired bacteraemia and the risk of catheterassociated urinary tract infections. Postgrad. Med.J., 89 (1052), 329-334.

12. U.S. Environmental Protection Agency. 1989. Report to Congress on indoor air quality: Volume 2. EPA/400/1-89/001C. Washington, DC.

13. Bohatyr, V. B. (1986). Biological features of plants of the aroid family, promising for landscaping interiors. PhD (Botanika). Kyiv [in Russian].

14. Hrodzynskyy, A. M. (1981). Phytodesign and phytoncides. Kyiv [in Russian].

15. Zaimenko, N. V. (2001). Scientific principles of structural and functional construction of artificial biogeocenoses (in the system: soil - plant - soil). (Doctoral dissertation) (Botanika). Kyiv [in Ukrainian].

16. Zaimenko, N. V. (2008). Scientific principles of structural and functional construction of artificial biogeocenoses in the system soil - plant - soil. Kyiv: Naukova dumka [in Ukrainian].

17. Snezhko, V. V. (1983). Decorative and bioecological characteristics of plants in phytodesign. PhD (Botanika) Kyiv [in Russian]. 18. Snezhko, V. V. (1987). Recommendations on the use of ornamental plants for landscaping industrial interiors. Kyiv: Bot. sad. [in Russian]. 
19. Snizhko, V. V. (1981). Types of interiors in landscaping the human environment. Introduction and acclimatization of plants in Ukraine, 18, 77-79 [in Ukrainian].

20. Kharytonova, I. P. (2004). Research on phytodesign in the NBS. M.M. Grishka NAS of Ukraine. Introduction of plants, 1 , $52-56$.

21. Kharytonova, I. P. (2005). Biological features of tropical and subtropical plants in different types of interiors. PhD (Botanika). Kyiv [in Ukrainian].

22. Cherevchenko, T. M., Snezhko, V. V. (1986). Methods and techniques of landscaping interiors (recommendations). Kyiv: Bot. sad. [in Russian].

23. Cherevchenko, T. M., Lavrenteva, A. M., Ivannikov, R. V. (2008). Biotechnology of tropical and subtropical plants in vitro. Kyiv: Naukova dumka [in Russian].

24. Cherevchenko, T. M., Buyun, L. I., Ivannikov, R. V. (2012). Modern biotechnologies in the introduction of species of tropicogenic flora as a method of preserving their gene pool ex situ and enrichment of plant resources of Ukraine. Kyiv: Fitosotsiotsentr [in Ukrainian].

25. Tsybulya, N. V., Fershalova, T. D., Yakimova, Yu. L. (2010). Examination of the antimicrobial activity of some Begonia L. species as a possible piece of phytodesign. Aerospace and Environmental Medicine, 44 (1), 47-50.

26. Padhy, P. K., Rashney, C. K. (2005). Emission of volatile organic compounds (VOC) from tropical plant species in India. Chemosphere, 59, 1643-1653.

27. Podred, A. S., Labynskoy, E. H. (2008.) Guide to medical microbiology. In: General sanitary microbiology. Moscow: Binom [in Russian].

Received 11.10.19

Revised 17.12.19

Accepted 15.01.20

Л.І. Буюн ${ }^{1}$, Р.В. Іванніков ${ }^{1}$, В.М. Якимещь ${ }^{2}$,

Р.С. Степаньков ${ }^{3}$, І.П. Харитонова ${ }^{1}$, А.А. Кожокару ${ }^{4}$

${ }^{1}$ Національний ботанічний сад імені М.М. Гришка НАН України, вул. Тімірязєвська, 1, Київ, 01014, Україна,

+380 44285 2647, nbg@nbg.kiev.ua

2 Державна наукова установа «Центр інноваційних медичних технологій» НАН України,

Вознесенський узвіз, 22, Київ, 04053, Україна,

+380 44272 2205, cimtnanu@ukr.net

${ }^{3}$ ТОВ «ТОПЕНЕРДЖІ»,

вул. Миколи Василенка, 7, оф. 314, Київ, 03680, Україна,

+380 44220 9013, roman@topenergy.com.ua

${ }^{4}$ Українська військово-медична академія Міністерства оборони України,

вул. Московська, 45/1, корп. 33, Київ, 01015, Україна,

+380 44280 0034, umma@ukrpost.ua

\section{ФІТОМОДУЛЬНИЙ КЛАСТЕР ЯК СТРУКТУРНИЙ ЕЛЕМЕНТ \\ IНТЕР'СРУ ВНУТРІШНІХ ПРИМІЩЕНЬ \\ РІЗНОГО ФУНКЦІОНАЛЬНОГО ПРИЗНАЧЕННЯ}

Вступ. Сьогодні людину оточують нові токсичні речовини, які супроводжують технічний прогрес, а тому пошук нових способів очищення повітря набуває все більшої актуальності.

Проблематика. У сучасних умовах виникає гостра необхідність розробки методів фіторемедіації повітря приміщень, в яких упродовж тривалого часу перебуває значна кількість людей - профілактично-лікарняних закладів, аудиторій, військових казарм, житлових приміщень тощо.

Мета. Створення кластерних фіторемедіаційних модулів для оптимізації повітряного середовища приміщень.

Матеріали й методи. Використано анатомо-морфологічні, фізіолого-біохімічні, мікробіологічні методи, методи світлової та скануючої електронної мікроскопії.

Результати. Здійснено відбір з колекції тропічних рослин Національного ботанічного саду імені М.М. Гришка рослин-біофільтрів, що вирізняються підвищеною здатністю до поглинання шкідливих речовин з повітря. Визначено 
кількісні та якісні критерії будови листка та фотосинтетичного апарату, що визначають цю здатність рослин. Опрацьовано біотехнологічні методи розмноження рослин для фітомодулів. Підібрано типи контейнерів із системою автополиву та субстрати з низькою часткою органічної речовини. Спроєктовано та виготовлено світлодіодні фітолампи, кількісні та якісні характеристики яких відповідають оптимуму фотосинтетичних процесів. Проведено скринінг антимікробної активності фітомодулів за умов стаціонарних відділень ДНУ «Центр інноваційних медичних технологій НАН України». Показано, що контамінація повітря Staphylococcus saprophyticus після двотижневої експозиції зменшилась удвічі.

Висновки. До впровадження у лікарняно-профілактичних закладах та у місцях закритої дислокації підрозділів силових структур запропоновано фітомодулі, які містять види рослин, що є нетоксичними, мають високу ремедіаційну здатність та толерантні до різних абіотичних чинників.

Ключові слова: тропічні рослини, фіторемедіаційні модулі, антимікробна активність, адаптаційна здатність, смартфітолампи. 